\title{
Inhibition of mammary epithelial apoptosis and sustained phosphorylation of Akt/PKB in MMTV-IGF-II transgenic mice
}

\author{
RA Moorehead, ${ }^{1,2}$ JE Fata, ${ }^{1,2}$ MB Johnson ${ }^{1,2}$ and \\ R Khokha*,1,2 \\ ${ }^{1}$ Department of Medical Biophysics \\ 2 Department of Laboratory Medicine and Pathobiology, Ontario Cancer \\ Institute/University Health Network, University of Toronto, Toronto, Ontario, \\ M5G 2M9, Canada \\ * Corresponding author: R Khokha, Department of Medical Biophysics, Ontario \\ Cancer Institute, 610 University Avenue, Toronto, Ontario, M5G 2M9, Canada, \\ Tel: (416) 946-2051, Fax: (416) 946-2984, e-mail: rkhokha@oci.utoronto.ca.
}

Received 31.3.00; revised 27.7.00; accepted 7.8.00

Edited by Dr Green

\begin{abstract}
IGF-II is a growth factor implicated in human cancers and animal tumor models. While the mitogenic properties of IGF-II are well documented, its ability to suppress apoptosis in vivo has never been proven. We generated independent MMTVIGF-II transgenic mice to examine the control of epithelial apoptosis at the morphological, cellular and molecular levels during the physiological event of postlactation mammary involution. Transgenic IGF-II expression was achieved in mammary epithelium and increased IGF-II bioactivity was confirmed by phosphorylation of the insulin receptor substrate-1, a signaling molecule downstream of the type I IGF receptor. IGF-II overexpression induced a delay in mammary involution, as evident by increased mammary gland to body weight ratios and persistence of both functionally intact lobulo-alveoli and mammary epithelial cellularity. The delayed mammary involution resulted from a significant reduction in mammary epithelial apoptosis, and not from increased epithelial proliferation. Recombinant IGF-II pellets implanted into involuting mammary glands of wild-type mice provided further evidence that IGF-II protein inhibited local epithelial apoptosis. At the molecular level, phosphorylated Akt/PKB, but not Erk1 or Erk2, persisted in IGF-II overexpressors and temporally correlated with reduced epithelial apoptosis. Levels of the phosphatase PTEN were unaltered in the transgenic tissue suggesting that the maintenance of Akt/PKB phosphorylation resulted from sustained phosphorylation rather than altered dephosphorylation of PIP-3. Together, this data reveal that IGF-II inhibits apoptosis in vivo and this effect correlates with prolonged phosphorylation of Akt/PKB Cell Death and Differentiation (2001) 8, 16-29.
\end{abstract}

Keywords: IGF-II; transgenic mice; mammary involution; apoptosis; Akt/PKB
Abbreviations: Akt/PKB, protein kinase B; Erk, extracellular signalregulated kinase; IGF, insulin-like growth factor; IGFBP, insulin-like growth factor binding protein; IL-2, interleukin-2; IRS-1, insulin receptor substrate-1; MMTV, mouse mammary tumour virus; PIP-3, phosphatidylinositol $(3,4,5)$-triphosphate; PTEN, phosphatase and tensin homology deleted on chromosome 10

\section{Introduction}

By virtue of their ability to affect cell proliferation as well as cell death, survival factors can play a fundamental role in cancer development. Insulin-like growth factors (IGFs) are considered to be typical examples of survival factors. Components of the IGF axis that include the two ligands (IGF-I and IGF-II), the two receptors (IGF-IR and IGF-IIR), and the IGF binding proteins (IGFBPs) are often dysregulated in several human malignancies including breast cancer. ${ }^{1-3}$ While the properties of IGF-I that promote tumorigenesis have been extensively studied, the function of IGF-II is not well understood.

IGF-I and IGF-II are secreted molecules with distinct characteristics. Although, they elicit their mitogenic and antiapoptotic actions through the same IGF-IR receptor (reviewed $\mathrm{in}^{4}$ ), the two genes differ in vivo in their regulation and function. The levels of IGF-I mRNA increase 10-100-fold in most tissues after birth. ${ }^{5}$ In contrast, IGF-II mRNA levels are high during embryogenesis but decline during adulthood. ${ }^{6}$ Circulating levels of growth hormone regulate the hepatic and extrahepatic production of IGF-I, while IGF-II production is not intimately linked to growth hormone levels. ${ }^{7}$ The significance of IGF-I and IGF-II becomes apparent in animals that lack these genes. Targeted disruption of the IGF-I gene induces death, infertility, and deficiencies in ossification, muscle and lung development, whereas the lack of IGF-II results in viable, fertile, proportionate dwarfs. ${ }^{8-10}$ Differences between IGF-I and IGF-II also extend to their role in breast cancer. IGF-II mRNA and protein is more frequently detected in primary tumors and human breast cancer cell lines than IGF-I. ${ }^{11}$ In addition, clinical studies show that stromal cells surrounding normal breast epithelium secrete IGF-I while those surrounding the malignant epithelium secrete IGF-II, suggesting that transformation of breast epithelial cells may be associated with a switch from stromal IGF-I to IGF-II expression. ${ }^{12,13}$ In rodents, the IGFII gene is normally imprinted, but is frequently reactivated upon oncogenic transformation in transgenic mice. ${ }^{14,15}$ Further, the transgenic expression of IGF-II in mouse mammary tissue leads to the development of mammary tumors after long latency, ${ }^{16}$ indicating a causal link between IGF-II activity and mammary tumorigenesis. It is clear that IGF-II plays a role in modulating breast cancer, however the mechanisms underlying its effects remain to be resolved. 
A potential mechanism by which IGF-II can promote mammary tumorigenesis is through inhibiting apoptosis. A large body of in vitro and in vivo evidence demonstrates that IGF-I inhibits apoptosis in several cell types. ${ }^{17-23}$ On the other hand, the antiapoptotic properties of IGF-II have been shown in vitro, but remain to be proven in vivo. The intracellular molecules responsible for mediating cell survival downstream of the IGF-IR have also not been characterized in vivo. We asked the question whether and how IGF-II overexpression exerts antiapoptotic effects in vivo. To address this, the event of postlactation mammary involution was selected as a model for our studies. Extensive mammary epithelial proliferation and differentiation culminates in the generation of lobulo-alveoli for lactation. However, these structures undergo scheduled regression following the loss of suckling stimuli, accumulation of milk, and decrease in lactogenic hormones. The lobulo-alveolar collapse is a result of massive mammary epithelial apoptosis. ${ }^{24,25}$ These events can be synchronized by removal of the litter at a specific day of lactation and have been widely studied at the morphological, cellular and molecular levels. ${ }^{24,26-31}$ Therefore, postlactation mammary involution offered an appropriate model to uncover the effects of IGF-II on cellular apoptosis and to elucidate the underlying molecular events in a physiological environment.

We generated and characterized three distinct lines of transgenic mice overexpressing IGF-II in mammary epithelial cells by utilizing the MMTV promoter. Increased IGF-II bioactivity was demonstrated through elevated insulin receptor substrate-1 (IRS-1) phosphorylation. We show, genetically and biochemically, that IGF-II reduced mammary epithelial apoptosis and delayed postlactation mammary involution. Molecular analyses of transgenic mammary tissue revealed that the antiapoptotic effects might be mediated through the sustained phosphorylation of $\mathrm{Akt} / \mathrm{PKB}$, an antiapoptotic cytoplasmic protein.

\section{Results}

\section{Transgenic IGF-II expression in mammary epithelium of MMTV-IGF-II mice}

To derive transgenic mice expressing elevated levels of IGFII, an expression construct containing the full-length human IGF-II (hIGF-II) cDNA under the control of the MMTV-LTR (Figure $1 \mathrm{~A}$ ) was microinjected into one-cell zygotes. Founder animals were identified by probing Southern blots of Pst cleaved tail DNA with a hIGF-II DNA probe which detected an $833 \mathrm{bp}$ transgene-specific (t-IGF-II) fragment, as well as a $1391 \mathrm{bp}$ endogenous IGF-II (e-IGF-II) fragment (Figure 1B). Three male founders were identified (Ml1, Ml12 and Ml16) and an independent transgenic line established from each founder mouse.

Next we screened for IGF-II expression in the mammary tissue. Mammary mRNA from 35-day-old wild-type and transgenic mice was analyzed by RT-PCR using both transgene-specific and control primer sets. A forward primer located in the transcribed portion of the MMTV promoter and reverse primer in the IGF-II transgene (primers 1 and 3 , Figure 1A) produced $600-800 \mathrm{bp}$ fragments $(t)$ that were evident only in the mammary tissue of transgenic mice (Figure 1C). The 296 bp fragment generated from the interleukin-2 control (c) primers was visible in every lane and served as a positive control for individual PCR reactions. To further verify that the $600-800 \mathrm{bp}$ fragments were indeed the result of transgene expression, PCR fragments were transferred to nylon membrane and probed for the presence of the Ha-ras sequence that is present in the $5^{\prime}$ untranslated region of the expression construct. As shown in Figure 1C, Ha-ras expression $\left(\mathrm{t}^{\star}\right)$ was detected only in transgenic mammary tissue.

To assess whether transgenic IGF-II expression was restricted to the mammary tissue, RT-PCR analysis was performed on a number of organs. We found that salivary gland, spleen, and uterus also expressed t-IGF-II in all three independent transgenic lines while kidney, ovary, liver and pancreas, expressed t-IGF-II in some of the lines (data not shown). These organ-specific expression profiles were consistent with the literature describing MMTV-driven transgenes. $^{32,33}$ To compare the level of t-IGF-II expression among the three transgenic lines, quantitative RTPCR was performed utilizing primer sets for the IGF-II transgene (primers 2 and 3; Figure 1A) and endogenous HPRT. The latter served as an internal control for PCR amplification. These analyses indicated that both Ml1 and Ml12 mice had considerably higher transgene expression than Ml16 mice (data not shown). Thus, we had established three independent MMTV-IGF-II transgenic lines with different levels of ectopic t-IGF-II expression in the mammary gland.

To identify the cell types responsible for IGF-II production during involution, in situ hybridization was performed on mammary tissue isolated from day 3 of involution (d3i) using strand-specific IGF-II or Ha-ras riboprobes. IGF-II-specific signal was detected in epithelial cells of wild-type tissue, albeit at very low levels (Figure 1D), which is consistent with the findings of Richert and Wood. ${ }^{34}$ The transgenic mammary tissue showed IGF-IIspecific signal, which localized to epithelial cells (Figure $1 E)$. This signal was much more intense than the e-IGF-II and was present in a majority of epithelial cells. In situ hybridization with a Ha-ras riboprobe was used to confirm that the transgene expression was confined to the epithelial cells of transgenic animals (Figure 1F, G). Given that stageand site-specific expression of IGF-II occurred appropriately for our studies, these mice were subjected to further molecular analyses.

\section{Increased IGF-II bioactivity in MMTV-IGF-II mammary tissue}

To gauge the amount of transgenic IGF-II in relation to endogenous IGF-II, the levels of e-IGF-II and t-IGF-II mRNA were analyzed in wild-type and transgenic mice during involution by Northern blot and slot blot analyses. Very low levels of e-IGF-II mRNA were evident in mammary tissue from wild-type mice and these levels were maximal on days 10 of lactation and 1 of involution (Figure 2A). On the other hand, transgenic IGF-II mRNA was observed throughout involution, and its expression was 50-100-fold that of the e-IGF-II 
mRNA levels (Figure 2A). Thus the level of t-IGF-II was far greater than the e-IGF-II.

The IGFBPs play an important function in the IGF axis. They serve to transport IGFs and modulate their half-life, as well as regulate IGF:IGF receptor interactions (reviewed $\left.\mathrm{in}^{35,36}\right)$. Thus, the levels of IGFBPs in a given tissue can influence IGF-II bioavailability. A 50-fold increase in IGFBP5 and smaller increases in IGFBP-2 and IGFBP-4 have
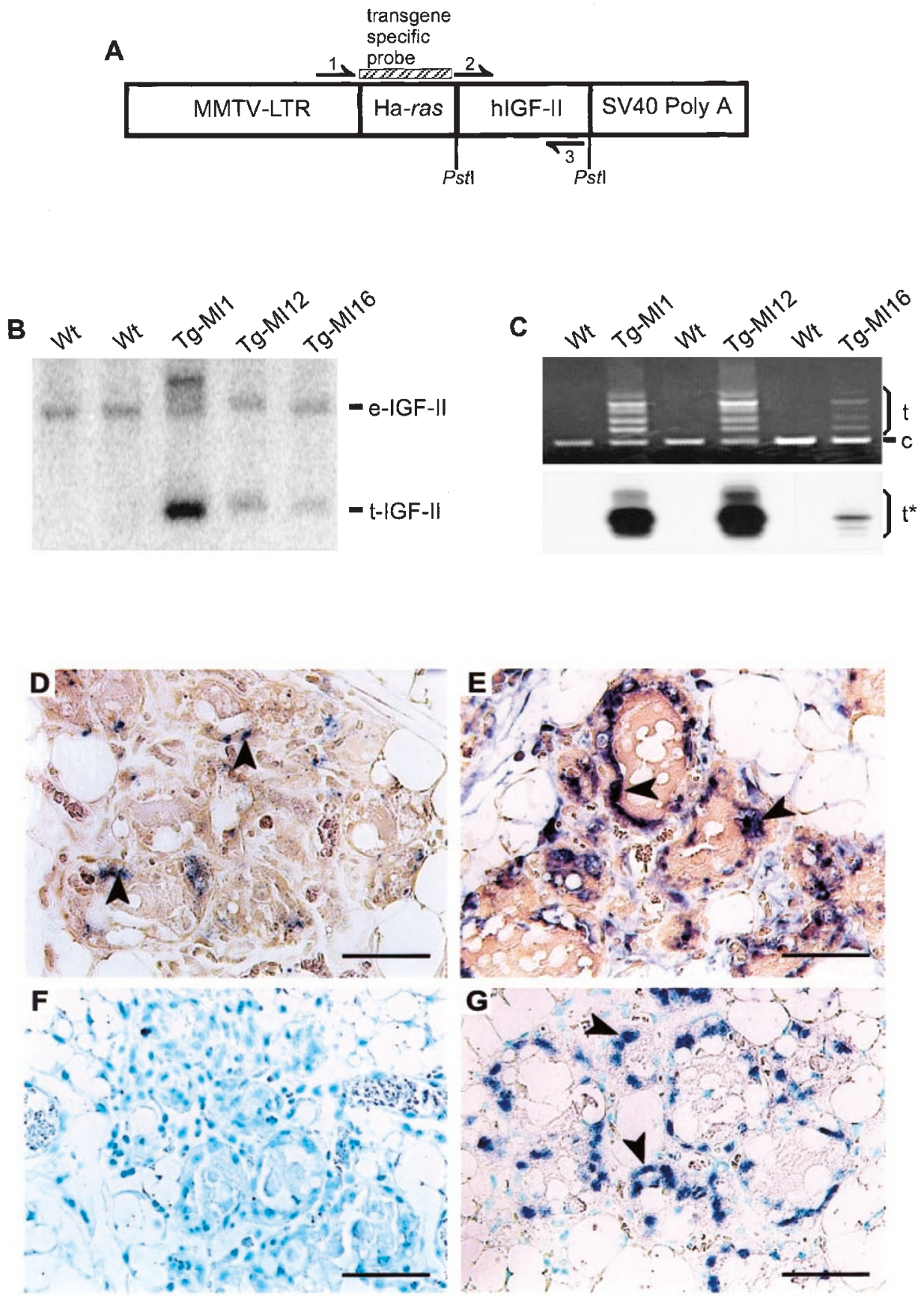

Figure 1 Generation and characterization of MMTV-IGF-II transgenic mice. (A) Transgenic expression cassette containing an MMTV-LTR promoter, an untranslated portion of the Ha-ras gene, full-length human IGF-II cDNA and a SV40 polyadenylation sequence. Numbers and arrows indicate the location of PCR primers. Primers 1 and 3 were used for RT - PCR while primers 2 and 3 were used for PCR genotyping of MMTV-IGF-II transgenics. (B) Southern analysis of IGF-II in wild-type (Wt) mice and MMTV-IGF-II transgenic (Tg) lines MI1, MI12, and MI16. The IGF-II transgene (t-IGF-II) was detectable in all three transgenic lines as an 833 bp fragment while the endogenous IGF-II (e-IGF-II) gene was detected in both wild-type and transgenic mice as a 1391 bp fragment. (C) RT - PCR of mammary RNA from 35-day-old MMTV-IGF-II transgenic and wild-type mice using primer sets specific for IGF-II (t; primers 1 and 3) and for a control (c) transcript (IL-2). Transgene expression was restricted to the three transgenic lines while the PCR product for the control transcript was apparent in all samples. Probing with a ${ }^{32} \mathrm{P}$ labeled Ha-ras probe (transgene-specific probe) confirmed that the PCR products were the result of transgene expression. In situ hybridization using a Dig-labeled IGF-II riboprobe on sections from (D) wild-type or (E) transgenic mammary tissue at d3i or a Dig-labeled Ha-ras riboprobe in (F) wild-type or (G) transgenic mammary tissue at $\mathrm{d} 3 \mathrm{i}$. Both probes demonstrated elevated levels of IGF-II expression in the mammary epithelial cells of the transgenic mice compared to controls. Arrowheads indicate positive stained cells; scale bars, $50 \mu \mathrm{m}$ 
been reported in the rat mammary tissue on day 2 of involution. ${ }^{37}$ We evaluated whether the levels of IGFBPs were altered in the IGF-II overexpressing mammary tissue, since a concomitant change in these binding proteins would influence the availability of t-IGF-II. Ligand blot analysis revealed that an IGFBP of $\sim 32 \mathrm{kDa}$ (possibly IGFBP-5) peaked at $\mathrm{d} 2 \mathrm{i}$ and remained detectable until $\mathrm{d} 4 \mathrm{i}$ in both genotypes (Figure 2B). Since the levels were comparable in transgenic and wild-type mice, we concluded that the increased IGF-II production in the transgenic mammary tissue was not confounded by altered IGFBP levels in the tissue. Overall, an increased amount of IGF-II was available to interact with its receptors in the MMTV-IGF-II mammary tissue.

IGF-II induces signal transduction primarily through the IGF-IR, ${ }^{38}$ although it has also been reported to stimulate insulin receptor signaling. ${ }^{39,40}$ The IRS-1 protein binds to activated IGF-IR, as well as to activated insulin receptor, becomes phosphorylated and propagates signal transduction from both of these receptors. We used immunoblotting
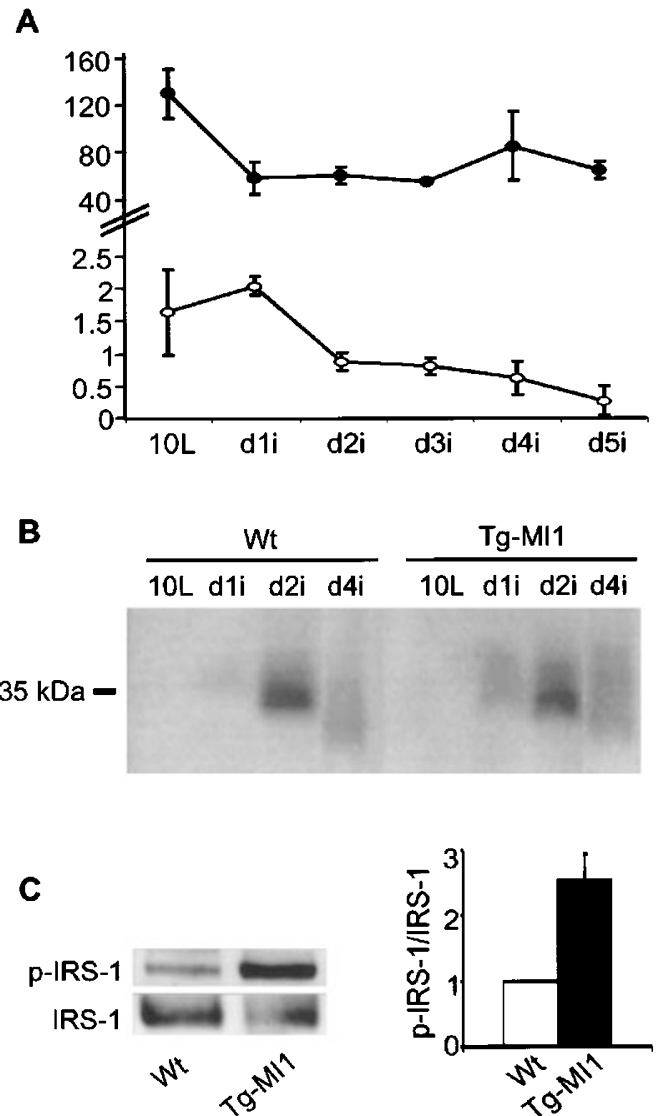

Figure 2 Mammary IGF-II bioactivity in MMTV-IGF-II transgenics. (A) Slot blot analysis of e-IGF-II and t-IGF-II mRNA relative to $18 \mathrm{~S}$ rRNA in involuting (O) wild-type and (O) transgenic mammary tissue from days $10 \mathrm{~L}$ to $\mathrm{d} 5 \mathrm{i}$. (B) Ligand blot of IGFBP levels in wild-type and transgenic mammary tissue during involution. (C) Western analysis of p-IRS-1 in wild-type and transgenic $10 \mathrm{~L}$ mammary tissue. The levels of $p-I R S-1$ and total IRS-1 were detected using antibodies specific to either the phosphorylated form of IRS or nonphosphorylated IRS-1 and quantified by densitometry with specific antibodies to monitor the levels of phosphorylated IRS-1 ( $p-$ IRS-1) and total IRS-1 protein. The ratio of $p$ IRS-1 to IRS-1 was taken as an indicator of t-IGF-II bioactivity in the transgenic tissue. The levels of $p$-IRS-1 were considerably higher in IGF-II overexpressing mammary tissue obtained at $10 \mathrm{~L}$, compared to that from controls (Figure 2C). Specifically, the ratio of $\mathrm{p}$-IRS-1 to total IRS-1 in the transgenic tissue was 2.5-fold that of the wild-type tissue (Figure 2D). An increase in the level of $p$ IRS-1 was also evident in 75-day-old virgin transgenic mammary tissue (data not shown). Together, these observations show that mammary overexpression of IGFII resulted in increased IGF-II bioactivity in the MMTV-IGF-II mice.

\section{Delayed mammary involution in MMTV-IGF-II transgenic mice}

Since extensive epithelial apoptosis is responsible for postlactation mammary involution, we selected this process as a model to delineate the impact of $t-I G F-I I$ expression on apoptosis in vivo. The following measures were implemented to ensure consistency in this system. We minimized the mouse-to-mouse variation that can arise from the suckling response by maintaining the litter size at five pups per female, and synchronized the onset of mammary involution by removing litters on day $10 \mathrm{~L}$. In addition, all mice were analyzed following their first pregnancy.

As an initial measure of the gross mammary alterations that ensue during involution, the weight of 4th-inguinal mammary fat pads relative to the body weight of the mouse, were monitored. An initial increase in this value was expected after pup removal due to milk accumulation, and was observed in both wild-type and transgenic mice at d1i. As involution proceeds, this ratio declines in a characteristic manner leveling out around $d 4 i$, a time period of maximal epithelial apoptosis. We found that the mammary gland-to-body weight ratio was consistently higher from $d 1 \mathrm{i}$ to $\mathrm{d} 4 \mathrm{i}$ in the MMTV-IGF-II mice compared to wild-type controls and these differences were significant at several of the time points (Figure $3 \mathrm{~A}$ ).

To ascertain whether elevated expression of IGF-II resulted in morphological alterations in the epithelial ductal structures, whole mount analyses were conducted on each day beginning at $10 \mathrm{~L}$ until d8i. At day $10 \mathrm{~L}$, the mammary gland is packed with large, milk-filled lobulo-alveoli. Progressive, scheduled involution then leads to lobuloalveolar regression that is followed by the clearing of mammary epithelial cellularity and the reconstitution of adipose tissue. We found that the process of mammary involution was delayed in IGF-II overexpressing mice. Specifically, the bud-like, lobulo-alveolar structures persisted for a longer period before regression in $\mathrm{Ml} 1$ transgenics and these differences were greatest at $\mathrm{d} 4 \mathrm{i}$ (Figure $3 \mathrm{~B}$ vs $3 \mathrm{C}$ ). It was clearly evident that many lobuloalveoli were still dilated and contained a secretory substance in the transgenic mice (arrowhead, Figure 3B), whereas these structures had regressed in wild-type mice (Figure $3 \mathrm{C}$ ). Further, an increase in $\beta$-casein mRNA expression relative to $18 \mathrm{~S}$ rRNA expression was observed 

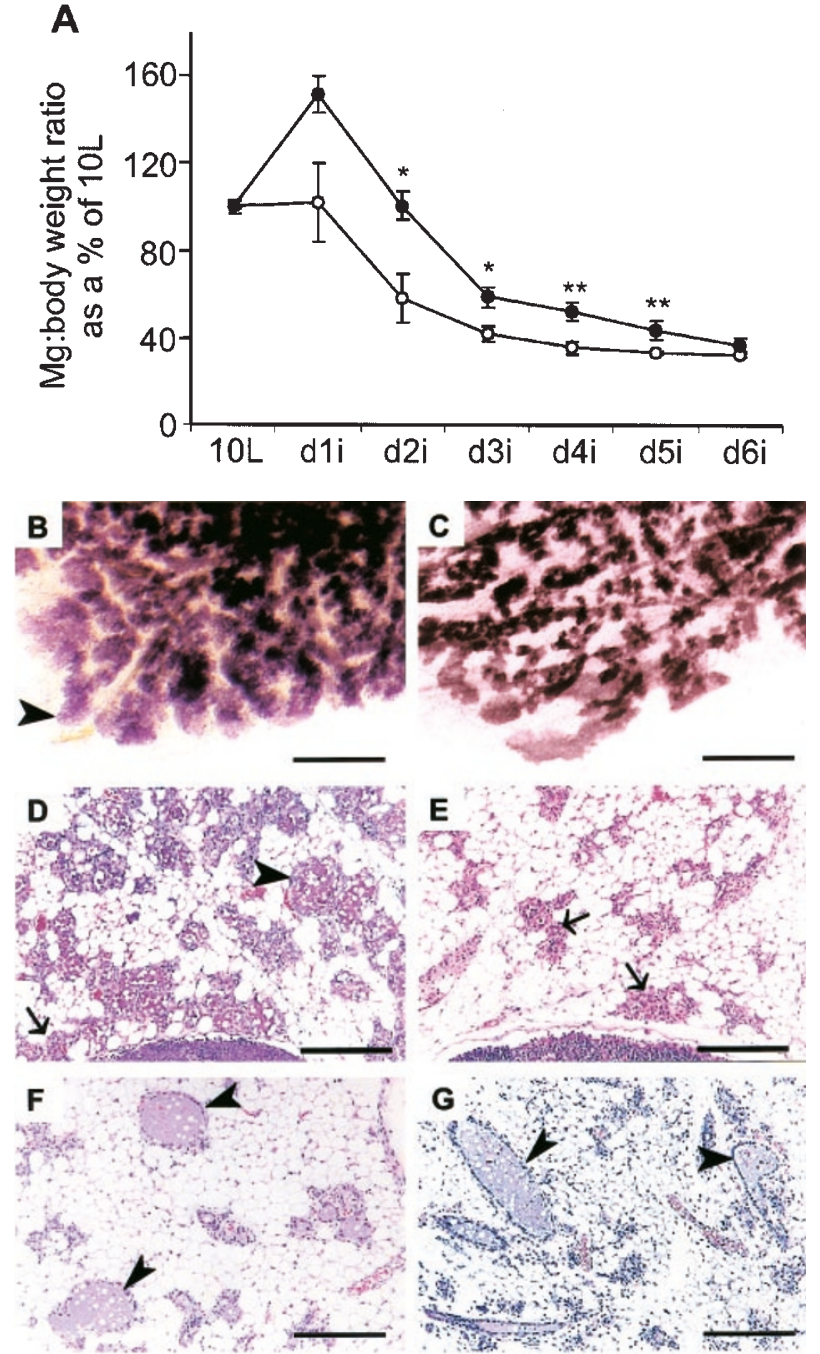

H
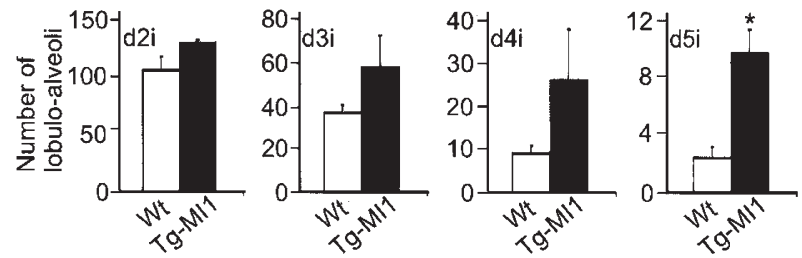

Figure 3 (A) Mammary gland (Mg) to body weight ratios during involution in (-) transgenic and $(O)$ wild-type mice. Values are presented as mean $+S E M$ $\left(^{*}\right) P<0.09,\left(^{* *}\right) P<0.05$. Whole mount analysis of involuting 4th-inguina mammary glands in (B) transgenic and (C) wild-type mice at d4i. Arrowheads indicate dilated lobulo-alveoli; scale bars, $800 \mu \mathrm{m}$. Hematoxylin/eosin-stained sections of (D) transgenic and (E) wild-type mice at d4i. Arrowheads indicate structurally intact lobulo-alveoli while arrows indicate collapsed lobulo-alveoli, scale bars, $200 \mu \mathrm{m}$. Hematoxylin/eosin-stained sections of $\mathrm{d} 5 \mathrm{i}$ involuting mammary tissue in $(\mathbf{F})$ Ml16 transgenic mice and $(\mathbf{G})$ Ml1 double hemizygous transgenic mice. Arrowheads indicate structurally intact lobulo-alveoli, scale bars, $200 \mu \mathrm{m}$. (H) Quantification of the number of structurally intact lobuloalveoli in wild-type and transgenic mice spanning days 2-5 of involution. Values are presented as mean \pm SEM and were considered significantly different $\left(^{*}\right)$ when $P<0.05$ in transgenic mammary tissue at $10 \mathrm{~L}$ and $\mathrm{d} 1 \mathrm{i}$ (data not shown). This suggested that the lobulo-alveoli in the transgenic mice also differed functionally from those in control mice.

Next we performed histological analyses to assess the differences at the cellular level between transgenic and wild-type tissue. The mammary tissue has distinct compartments; connective tissue composed of adipocytes and extracellular matrix and parenchymal tissue composed of epithelial and myoepithelial cells. At $10 \mathrm{~L}$, the mammary gland is composed entirely of a parenchymal compartment with functional lobulo-alveoli and this compartment is removed via apoptosis during mammary involution. Typically, lobulo-alveoli begin to collapse around $\mathrm{d} 3 \mathrm{i}$ and cords of mammary epithelial cells predominate by $\mathrm{d} 5 \mathrm{i}$. We performed two measurements: first, we determined the percentage of mammary tissue occupied by the parenchymal compartment and found this value to be increased in involuting transgenic mammary tissue on days spanning d3i-d6i. Significant differences between Ml1 transgenic and wild-type mice were observed on $\mathrm{d} 5 \mathrm{i}$ and $\mathrm{d} 6 \mathrm{i}(23.6 \% \pm 1.6$ vs $11.3 \% \pm 2.1, P<0.005$ on $\mathrm{d} 5 \mathrm{i} ;$ and $14.9 \% \pm 1.5$ vs $6.9 \% \pm 1.2, P<0.01$ on $\mathrm{d} 6 \mathrm{i})$. Second, we compared the number of structurally intact lobulo-alveoli remaining on specific days of involution. Lobulo-alveolar regression normally occurs earlier in the post-nodal area (from the end of the mammary fat pad to lymph node) than in the prenodal area (from lymph node to teat). To maintain consistency we quantified the numbers of lobulo-alveoli in the post-nodal area. Lobulo-alveolar collapse was clearly delayed in Ml1 transgenic mammary glands at d4i (Figure $3 \mathrm{D}$ vs E) and a higher number of lobulo-alveoli were present from $\mathrm{d} 3 \mathrm{i}$ to $\mathrm{d} 6 \mathrm{i}$ in the mammary glands of transgenic mice than of controls (Figure $3 \mathrm{H}$ ). This phenotype was not a result of increased epithelial proliferation as the percentage of BrdU positive epithelial cells was not significantly different in the transgenic mammary tissue (data not shown). To rule out the possibility that these phenotypes arose from events other than increased IGF-II expression, such as the site of transgene integration, independent transgenic lines (MI12 and Ml16) as well as the Ml1 double hemizygous (carrying two IGF-II alleles) mice were subjected to similar analyses on day 5 of involution. An elevation in the mammary cellularity, as indicated by the parenchyma compartment was observed in Ml12 (23.6\%) and Ml16 (26.6\%) mice and this value was further increased in Ml1 double hemizygous transgenics (37.4\%). In addition, multiple intact lobuloalveoli persisted in Ml16 (Figure 3F) and Ml1 double hemizygotes (Figure $3 \mathrm{G}$ ) at $\mathrm{d} 5 \mathrm{i}$, a time when the majority of these structures have regressed in wild-type mice. This demonstrated that the phenomenon of delayed mammary involution occurred consistently in independent MMTV-IGFII lines.

\section{Decreased mammary epithelial apoptosis in MMTV-IGF-II mice}

To determine the basis of increased mammary cellularity in the transgenic tissue, we elucidated the apoptotic 
index of mammary epithelial cells throughout involution by immunohistochemistry (Figure 4A, B). It is known that programmed cell death is responsible for lobulo-alveolar collapse and removal of epithelial cells. We observed two classes of lobulo-alveolar structures, those that had collapsed and consisted primarily of apoptotic cells, and those appearing essentially intact and consisted primarily of viable epithelial cells. Separate measurements were performed for all apoptotic epithelial cells within the mammary gland and for apoptotic epithelial cells within intact lobulo-alveoli. Kinetics of apoptosis during scheduled involution in wild-type mice showed that apoptotic cells were first detected at $\mathrm{d} 1 \mathrm{i}$ and peaked at $\mathrm{d} 4 \mathrm{i}$, which was consistent with published reports. ${ }^{27,30,41}$ The percentage of total mammary epithelial apoptosis in MMTV-IGFII mice lagged behind that of the controls (data not shown). When intact lobulo-alveoli were considered, apoptotic cells could not be detected until d2i (Figure 4C) in the IGF-II overexpressors whereas apoptotic epithelial cells were observed at $\mathrm{d} 1 \mathrm{i}$ in wild-type mice. Further, the numbers of apoptotic cells were approximately half of those observed in the control tissue, from d3i to d5i $(P<0.05$, Figure $4 \mathrm{C})$.

\section{Decreased epithelial apoptosis correlates with sustained phosphorylation of Akt/PKB}

We further explored the molecular basis of the antiapoptotic effect of IGF-II. A number of in vitro studies have shown that IGF-I and IGF-II inhibit apoptosis through the activation of Akt/ PKB. ${ }^{42-45}$ We investigated whether reduced mammary epithelial apoptosis in transgenic tissue was linked to activation of Akt/PKB. Western blots for Akt and p-Akt spanning $10 \mathrm{~L}$ to $4 \mathrm{di}$ from two independent sets of animals are presented in Figure 5A. Phosphorylated Akt/PKB was indeed detected at $10 \mathrm{~L}$ in both wild-type and transgenic mice and its levels increased approximately five fold at d1i (Figure $5 B$ ). In wild-type mice, the levels of $p-A k t / P K B$ diminished rapidly by $\mathrm{d} 2 \mathrm{i}$ and were undetectable thereafter. It was striking that the levels of phosphorylated Akt/PKB remained elevated until $\mathrm{d} 3 \mathrm{i}$ and were observed as late as $\mathrm{d} 4 \mathrm{i}$ in the MMTV-IGF-II mice. Sequential probing of the Western blots provided a measure of total Akt/PKB in the tissue.

$A k t / P K B$ phosphorylation is regulated by the phosphorylation status of the lipid phosphatidylinositol $(3,4,5)$ triphosphate (PIP-3). Since the phosphatase PTEN can dephosphorylate PIP-3, levels of PTEN can limit the
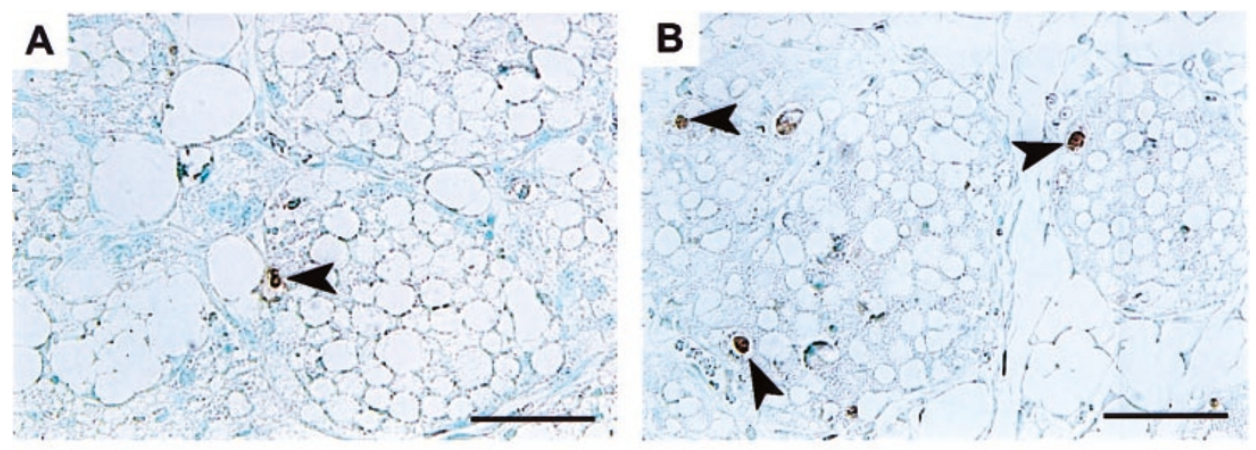

C

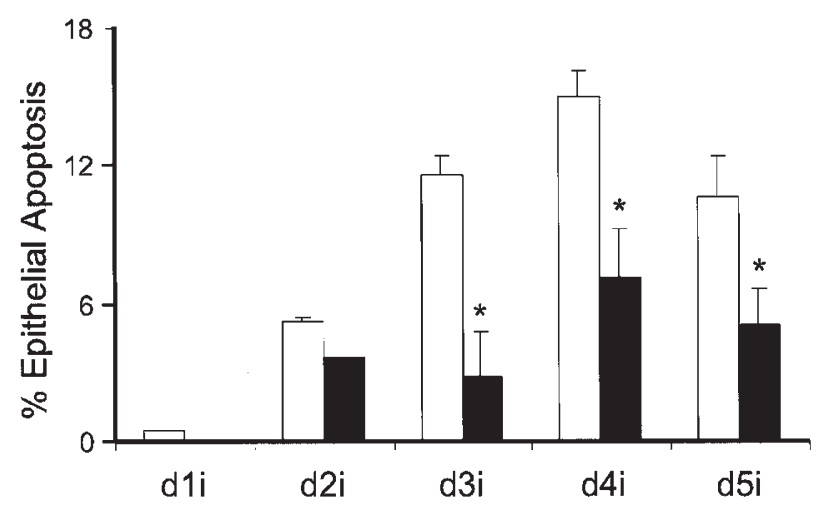

Figure 4 Mammary epithelial apoptosis during involution. Apoptotic epithelial cells were identified immunohistochemically in (A) transgenic and (B) wild-type d3i mammary tissue. Arrowheads indicate apoptotic cells, scale bars $50 \mu \mathrm{m}$ (C) Percentage of apoptotic epithelial cells comprising structurally intact lobulo-alveoli in $(\square)$ wild-type and ( $\square$ ) Ml1 transgenic mice. Values represent mean \pm SEM of at least three mice at d4i and d5i and at least two mice at all other time points. Differences were considered significant $\left(^{*}\right)$ when $P<0.05$ 
A

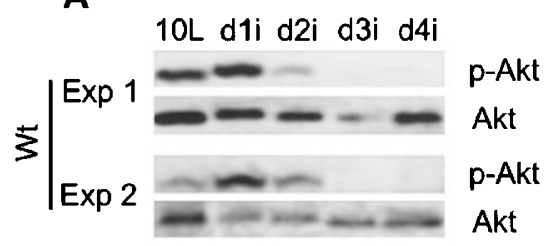

$10 L d 1 i d 2 i d 3 i d 4 i$

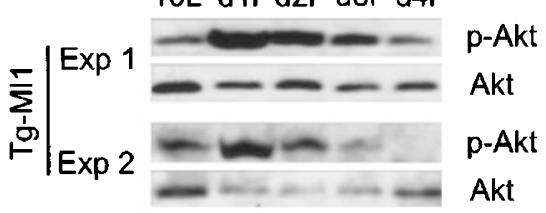

C

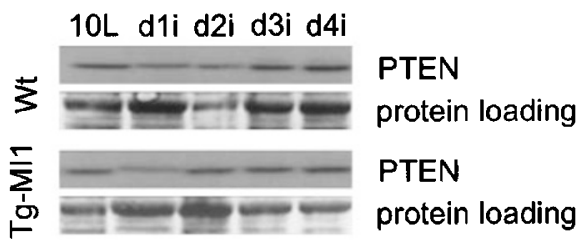

D

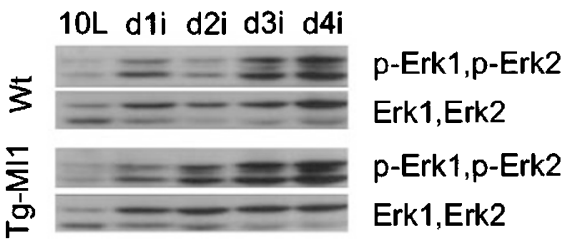

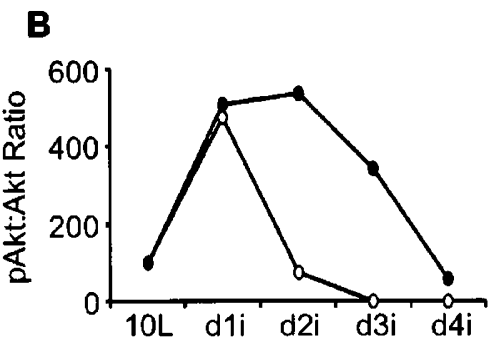

Figure 5 Western analysis of wild-type and transgenic mammary tissue spanning days $10 \mathrm{~L}$ to d4i. (A) Levels of Akt/PKB as detected by the anti-phosphoAkt(Ser473) and anti-Akt antibodies in two independent sets of animals. (B) Quantification of the average levels of phosphorylated Akt/PKB normalized to the total levels of Akt/PKB in the two experiments in $(O)$ wild-type and $(\mathbf{O})$ transgenic mice. Values on the Y-axis are arbitrary units. (C) Levels of PTEN protein. Lower panels represent the amido black-stained membrane to show protein loading. (D) Levels of phosphorylated Erk1 and Erk2 as well as total Erk 1 and Erk 2 protein

duration of Akt/PKB phosphorylation. ${ }^{46-48}$ There were no differences in the levels of PTEN protein in the wild-type versus the transgenic mammary tissue (Figure $5 \mathrm{C}$ ). Interestingly, it appeared that the levels of PTEN protein began to increase at $\mathrm{d} 3 \mathrm{i}$, the time the $A \mathrm{kt} / \mathrm{PKB}$ phosphorylation was lost.

Although the downstream targets of Akt/PKB are still poorly understood it has been demonstrated that Akt/PKB can phosphorylate Bad in tissue culture systems (reviewed $\left.i^{49-51}\right)$. We attempted to assess the phosphorylation status of Bad in our mammary tissue. The phosphorylation-specific antibody (Ser112) was unable to detect phosphorylated Bad during the events of physiological apoptosis (data not shown).

Activation of Erk1 and Erk2 has also been implicated in inhibiting apoptosis, possibly through phosphorylation of Bad. $^{52,53}$ Since IGF-II-mediated signaling through the IGFIR can stimulate the Erk pathway ${ }^{4}$ we examined the levels of phosphorylated Erk1 and Erk2 to seek the involvement of this pathway in the antiapoptotic response of IGF-II. The levels of phosphorylated Erk1 and Erk2 were lowest at $10 \mathrm{~L}$ and increased as involution proceeded. There were no differences in Erk1 or Erk2 in the wild-type and transgenic involuting mammary tissue. If these proteins had a function in the physiological antiapoptotic response of IGF-II, higher levels of phosphorylated Erk1/Erk2 at $10 \mathrm{~L}$ to d2i would be expected. Together, this data revealed that Akt/PKB is possibly involved in the antiapoptotic signaling of IGF-II in vivo.

\section{Normal postlactation epithelial apoptosis is inhibited by IGF-II slow-release pellets}

Low levels of IGF-II exist during murine mammary morphogenesis, ${ }^{34}$ and we had observed low IGF-II expression during the period of postlactation involution (Figure 2A). To investigate whether elevating IGF-II during normal mammary involution would directly inhibit mammary epithelial apoptosis, a biochemical approach was used with topical application of recombinant IGF-II. Elvax-40 slow-release pellets containing $500 \mathrm{ng}$ of rlGF-II were implanted in the 4th-inguinal mammary gland of wild-type mice on d2i, in the post-nodal area. An inert control pellet that lacked IGF-II was implanted in the contralateral tissue of each mouse. Due to the identical hormonal milieu of the two glands, the contralateral tissue serves as an ideal control. Epithelial apoptosis surrounding either a pellet containing rlGF-II or a control pellet, detected immunohistochemically, is shown in Figure 6A, B respectively. A significant decrease in the apoptotic index of epithelial cells in the immediate vicinity of the implanted rIGF-II pellets was found in tissue removed at d5i (Figure 6C). This provided an independent confirmation that an elevation of IGF-II protein directly inhibited the normal mammary epithelial apoptosis.

\section{Discussion}

We have generated independent MMTV-IGF-II transgenic mice and examined epithelial apoptosis at the morphological, 

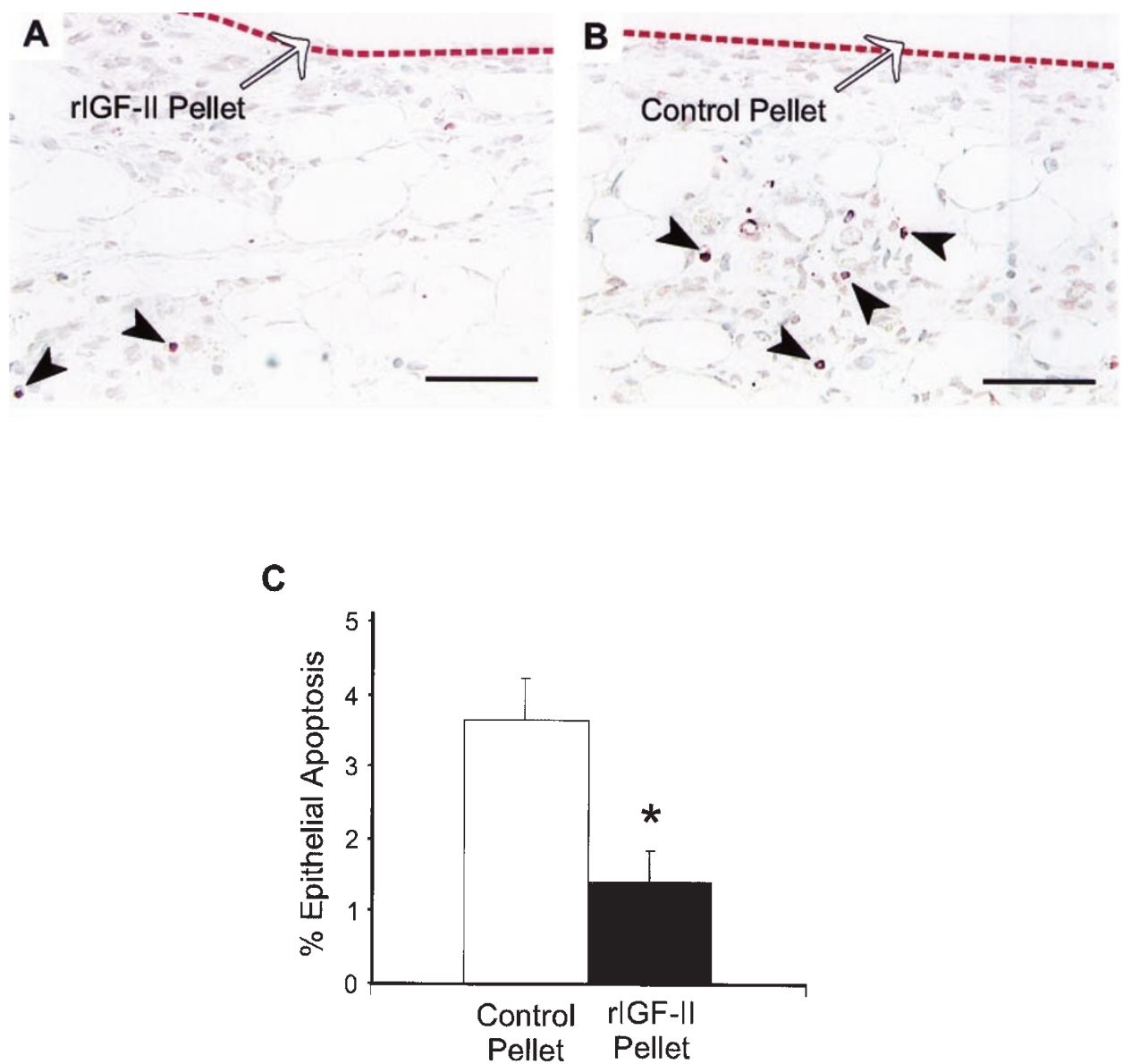

Figure 6 Mammary epithelial apoptosis 3 days after implantation of (A) a pellet containing rIGF-II or (B) a control pellet in the 4th-inguinal mammary gland of wildtype mice. Arrowheads indicate apoptotic cells, scale bars $50 \mu \mathrm{m}$. (C) Quantification of the percentage of mammary epithelial cells undergoing apoptosis surrounding either $(\square)$ a control pellet or $(\boldsymbol{\square})$ a pellet containing rIGF-II. Values represent mean \pm SEM of five animals and these values were considered statistically significant $\left(^{*}\right)$ when $P<0.05$

cellular and molecular levels during the physiological event of postlactation mammary involution. Here we provide the first in vivo demonstration of the anti-death role of IGF-II during physiological apoptosis. The antiapoptotic effect of IGF-II was initially evident in the involuting mammary glands as a delayed onset of mammary weight loss, slower lobuloalveolar involution of mammary tissue at the morphological level, and higher epithelial cellularity at the tissue level, when compared to controls. This resulted from a delayed onset of epithelial apoptosis rather than altered proliferation. The antiapoptotic effect of IGF-II was confirmed biochemically. Elevating IGF-II protein levels through implantation of a slowrelease pellet directly led to a local reduction of epithelial apoptosis within the involuting tissue. Downstream of the IGF$I R$, sustained phosphorylation of Akt/PKB throughout the period of delayed epithelial apoptosis confirmed that this negative regulator of apoptosis contributed to the antiapoptotic effects of IGF-II in vivo. This study provides further evidence that the contribution of IGF-II to breast tumorigenesis may extend beyond its known proliferative capacity.

\section{Role of the IGF axis in mammary involution}

The survival of mammary alveolar epithelial cells during lactation is dependent on a number of factors including prolactin and growth hormone. It was originally proposed that growth hormone suppressed alveolar epithelial apoptosis through elevating the levels of IGF-I and/or IGF-II. ${ }^{54}$ However, subsequent studies in which rats were subcutaneously administered IGF-I, IGF-II or IGFs complexed with IGFBP-3, failed to mimic the survival effects of growth hormone during involution. $^{55,56}$ Such an inability of the IGFs to inhibit apoptosis has been attributed to changes in the levels of IGFBPs that concomitantly occur during involution. ${ }^{37,57}$ It is thought that IGFs present in the milk act as survival factors, but the elevation of IGFBPs during involution effectively sequester the IGFs. This prevents the interaction of IGFs with the IGF-IR, essentially removing the IGF survival signal from mammary epithelial cells. ${ }^{37,57}$ In support of this concept are the findings that when sufficient levels of IGF-I are attained through transgenic overexpression, IGF-I suppresses apop- 
tosis and promotes epithelial cell survival during mammary involution. ${ }^{17,58}$

The involvement of IGF-II in mammary involution has not been studied. Until a recent publication by Richert and Wood $^{34}$ it was generally believed that IGF-II was not expressed in adult murine mammary tissue. ${ }^{8,59}$ Our in situ hybridization with a riboprobe specific for IGF-II extended the findings of Richert and Wood ${ }^{34}$ in that IGF-II was also expressed during postlactation involution within mammary epithelial cells, albeit at low levels. Further, we found that the levels of endogenous IGF-II increased from $10 \mathrm{~L}$ to $\mathrm{d} 11$ and declined thereafter, suggesting that it may play a role in mammary involution. The decrease in endogenous IGF-II expression after d1i, coupled with a dramatic increase in IGFBP levels at $\mathrm{d} 2 \mathrm{i}$, likely removes the IGF-II-mediated survival signals. In our genetic approach, much higher levels of IGF-II were achieved throughout involution in the transgenic tissue. This IGF-II expression, in the absence of concurrent IGFBP elevation, maintained IGF-II-mediated survival signaling and delayed mammary epithelial apoptosis and lobulo-alveolar collapse. The same effect was obtained when a biochemical approach was used. Implantation of IGF-II pellets in the mammary tissue of wild-type mice inhibited local mammary epithelial apoptosis. These observations highlight the potential for IGF-II, like IGF-I, to regulate natural mammary involution.

\section{The antiapoptotic property of IGF-II may underlie its tumorigenic potential}

Based on previous studies in transgenic systems, a causal relationship has emerged between IGF-II expression and cancer formation in several tissues (reviewed $\mathrm{in}^{11}$ ). For example, the transgenic expression of IGF-II has been associated with lymphomas and hepatocellular carcinomas ${ }^{60}$ (and reviewed $\mathrm{in}^{61}$ ), and its expression from a mammaryspecific sheep $\beta$-lactoglobulin promoter leads to mammary tumorigenesis. ${ }^{16}$ Further, the normally silent IGF-II gene often becomes reactivated during viral oncogene-driven tumorigenesis, such as that observed in pancreas ${ }^{15}$ and liver. ${ }^{14}$ While IGF-II expression is temporally coordinated with the onset of proliferation in some of these models, ${ }^{14,15,62}$ it is conceivable that its antiapoptotic property also plays a crucial role in the genesis of cancer. This may be especially applicable to the mammary gland since this tissue experiences repeated and extensive epithelial turnover throughout female life; during each round of the estrous cycle, ${ }^{63}$ (Fata and Khokha, unpublished data) and postlactation involution. $24,26-31$

Our investigations used both genetic and biochemical approaches to conclusively show that IGF-II suppressed mammary epithelial apoptosis in vivo during postlactation mammary involution. Based on these observations we propose that the low incidence of mammary tumorigenesis seen in IGF-II transgenics such as the $\beta$-lactoglobulin-IGF-II mice, ${ }^{16}$ may be initiated by incomplete epithelial apoptosis, a hypothesis that was not examined by this group. It has been shown that reduced mammary epithelial apoptosis due to $\mathrm{Bcl}-2$ overexpression, although insufficient to confer tumorigenesis, enhances the development of MMTVmyc-induced mammary tumors. ${ }^{64}$ These findings of reduced apoptosis are relevant since decreased mammary epithelial apoptosis is associated with an increased risk of fibrocystic changes and the development of carcinoma in premenopausal women. ${ }^{65}$ We are currently breeding our MMTV-IGF-II transgenic mice with mice that overexpress the neu oncogene to examine whether IGF-II-mediated inhibition of epithelial apoptosis augments neu-induced mammary tumorigenesis.

\section{In vivo molecular targets of IGF-II survival signaling}

We extended our finding of IGF-II-mediated inhibition of mammary epithelial apoptosis to the molecular level by examining downstream antiapoptotic signaling molecules. In vitro, the IGFs have been shown to inhibit apoptosis through the activation of Akt/PKB. ${ }^{42-44}$ Our analyses of the total and phosphorylated levels of $A k t / P K B$ revealed that $p-A k t / P K B$ was detectable in MMTV-IGF-II mammary tissue until d4i, while it disappeared after d2i in wild-type mice. The temporal decline of $p-A k t / P K B$ coincided with the peak of epithelial apoptosis during involution in both transgenic and wild-type mice. Specifically, minimal levels of apoptosis were observed at times of high levels of p-Akt/PKB, and high levels of mammary epithelial apoptosis were seen immediately after the levels of $p-A k t / P K B$ had substantially declined. Thus, the dynamics of Akt/PKB phosphorylation were consistent with its role as a negative regulator of apoptosis.

The dephosphorylation of Akt/PKB may, in part, relate to the changing levels of IGFBPs. Consistent with our finding that IGFBP levels peaked at $\mathrm{d} 2 \mathrm{i}$ in the mouse, a dramatic increase in IGFBPs has been reported at day 2 of involution in rats. ${ }^{37}$ Day $2 i$ is also the time when we observed a rapid decline in the levels of $p-A k t / P K B$ in wildtype mice. An increase in IGFBP levels at d2i likely reduced IGF bioavailability, which in turn, limited the downstream phosphorylation of Akt/PKB. Based on these findings we propose that t-IGF-II bioactivity and Akt/PKB phosphorylation was sustained in the MMTV-IGF-II transgenic tissue until d4i due to the high IGF-II:IGFBP ratio. The fact that IGFBP levels were comparable to those in wild-type mice while IGF-II expression was increased in the MMTV-IGF-II mice likely resulted in an abundance of free IGF-II available to stimulate IGF-IR and activate Akt/PKB.

Another potential regulator of Akt/PKB phosphorylation is the phosphatase PTEN. This molecule dephosphorylates PIP-3, which is then unable to promote Akt/PKB activation. ${ }^{46-48}$ We did not observe a differential regulation in the levels of PTEN protein among the wild-type and transgenic mice suggesting that the maintenance of $A k t / P K B$ phosphorylation was primarily driven by the increased availability of IGF-II rather than a reduction in the levels of PTEN. The eventual loss of Akt/PKB phosphorylation in transgenic mice may relate to the dependence of mammary epithelial cell survival on other parameters such as the contact with the extracellular matrix molecules, as discussed in the next section.

Exactly how Akt/PKB inhibits apoptosis remains unresolved. It has been proposed that Akt/PKB phosphorylates the proapoptotic molecule Bad and prevents its interaction with $\mathrm{Bcl}-2$ thus suppressing cytochrome $c$ release from 
mitochondria and subsequent apoptosis. ${ }^{51}$ We were unable to detect phosphorylated Bad in our involuting mammary tissue. This result was not completely unexpected as Bad is expressed at very low levels. ${ }^{51}$ In humans, another proposed downstream antiapoptotic target of Akt/PKB is caspase 9. Akt/PKB can phosphorylate human caspase 9 on Ser196 and inhibit its protease activity, ${ }^{66}$ however, this phosphorylation site is absent in mice ${ }^{56}$ and thus the relevance of caspase 9 in mediating the antiapoptotic effects of $A k t / P K B$ in murine tissue is unclear.

IGF-II also has the potential to inhibit apoptosis through the activation of Erk1 and Erk2. ${ }^{52,53}$ Since there was no difference in the levels of phosphorylated Erk1 or Erk2 in our transgenic mammary tissue it appears that this pathway does not significantly contribute to the antiapoptotic effects of IGF-II during involution.

\section{The antiapoptotic effects of IGF-II are influenced by structural factors}

Both soluble factors and contact with the basement membrane are critical for epithelial cell survival. ${ }^{24,26,27,67,68}$ When mammary epithelial cells are cultured on basement membrane, apoptosis induced by the withdrawal of lactogenic hormones can be inhibited by the addition of IGF-I or IGF-II. ${ }^{69}$ Also, IGF-mediated phosphorylation of IRS-1 and its association with $\mathrm{PI}-3$ kinase are enhanced in cells cultured on basement membrane suggesting that antiapoptotic signaling from the IGF-IR is more efficient when mammary epithelial cells are in contact with the basement membrane. ${ }^{69}$ Further, the IGFs are incapable of preventing apoptosis in the presence of an antibody that blocks the binding of mammary epithelial cells to laminin. ${ }^{69}$ Overall these studies indicate that soluble factors, such as the IGFs, act in concert with structural that blocks the binding of mammary epithelial cells to laminin. ${ }^{69}$ Overall these studies indicate that soluble factors, such as the IGFs, act in concert with structural signals, such as the extracellular matrix, in determining epithelial apoptosis. This also likely explains why transgenic IGF-II expression only delayed mammary gland involution and did not completely inhibit this process. The role of basement membrane degradation during involution and the regulation of the cleavage of IGFBPs by the matrix metalloproteinases, and the inhibition of this process by tissue inhibitors of metalloproteinases are currently under investigation in our lab.

\section{Phenotypes in IGF-II overexpressing transgenic mice}

Human IGF-II has been used to generate a number of transgenic strains that develop organ abnormalities as well as lymphomas, hepatocellularcarcinomasandlungadenocarcinomas. ${ }^{65,70-78}$ With respect to IGF-II overexpression in the mammary tissue, Bates et al ${ }^{79}$ have used the sheep $\beta$ lactoglobulin promoter and demonstrated mammary tumor formation albeit at a relatively low tumor incidence. This promoter induces transgene expression primarily during lactation. $^{80-82}$ In contrast, our use of the MMTV promoter resulted in transgene expression at all stages of mammary physiology: ductal development, lactation and involution. Our oldest mice are $\sim 18$ months and have yet to show overt mammary tumors. However, we have observed focal areas of epithelial hyperplasia in mammary glands of multiparous transgenic mice as well as sporadic tumors in other organs where MMTV-directed IGF-II is expressed (Moorehead and Khokha, unpublished observations). At present, it remains unresolved why IGF-II overexpression driven by the $\beta$ lactoglobulin promoter but not the MMTV promoter induces mammary tumors. It is difficult to compare the $\beta$-lactoglobulinIGF-II and MMTV-IGF-II mice since the basal level of transgene expression in the mammary tissue prior to tumor formation and the number of pregnancies required has not been reported for the $\beta$-lactoglobulin mice. ${ }^{16}$

In summary, this study represents the first report on the ability of IGF-II to inhibit physiological apoptosis. We also show that this antiapoptotic effect correlates with sustained phosphorylation of Akt/PKB and not Erk1 or Erk2. Based on the observation that PTEN protein levels are unaltered, we propose that the sustained phosphorylation of $A k t / P K B$ in the MMTV-IGF-II transgenics was propagated by continual IGF-II-mediated stimulation of molecules upstream of Akt/ PKB rather than their lack of dephosphorylation. These findings represent a potential mechanism through which IGF-II overexpression may predispose the mammary gland to tumor development.

\section{Materials and methods}

\section{The MMTV-IGF-II transgenic mice}

We made an MMTV-IGF-II expression vector by cloning an 833 bp PstlPstl full-length human IGF-II cDNA (from Dr. KJ Cullen, Georgetown University) downstream of the MMTV-LTR promoter (from Dr. W Muller, McMaster University). The MMTV-IGF-II construct also included an untranslated region of the Ha-ras gene and a SV40 polyadenylation sequence (Figure 1A). DNA was prepared for microinjection by digesting the MMTV-IGF-II expression vector with Sall and Spel. The cleaved DNA was electrophoresed through a $1 \%$ agarose gel and the transgenic cassette purified with a GeneClean II Kit (Bio/Can Scientific, Mississauga, ON, Canada) using the manufacturer's protocol. The expression construct was microinjected at a concentration of $1 \mathrm{ng} / \mu \mathrm{l}$ into the pronuclei of zygotes from FVB mice and microinjected zygotes were transferred to pseudopregnant FVB females.

Tail biopsies were taken from potential founders and incubated overnight at $55^{\circ} \mathrm{C}$ in a digestion buffer containing $20 \mathrm{mM}$ Tris $\mathrm{HCl}$ $\mathrm{pH}$ 8.0, $10 \mathrm{mM}$ EDTA pH 8.0, 0.5\% SDS and $0.4 \mathrm{mg} / \mathrm{ml}$ Proteinase $\mathrm{K}$. Tissue digests were agitated for 5 min using an Eppendorf mixer and $250 \mu \mathrm{l}$ of $6 \mathrm{M} \mathrm{NaCl}$ was added to each sample followed by an additional $5 \mathrm{~min}$ of mixing. Samples were centrifuged at $20000 \times \mathrm{g}$ for 7 min and DNA was precipitated with isopropanol. Ten micrograms of tail DNA was incubated overnight with Pstl at $37^{\circ} \mathrm{C}$ and the DNA was separated on a $1 \%$ agarose gel. Following transfer to Genescreen Plus nylon membrane (NEN Life Science Products, Boston, MA, USA), blots were probed with a ${ }^{32} \mathrm{P}$-dCTP-labeled human IGF-II probe. All ${ }^{32} \mathrm{P}$-labeled probes used in the present study were generated by random priming using a Prime-It II random primer labeling kit (Stratagene, La Jolla, CA, USA) following the manufacturer's protocol. Membranes were pre-hybridized and hybridized in Church buffer (7\% SDS, $1 \%$ BSA, $0.5 \mathrm{M} \mathrm{NaPi} \mathrm{pH} \mathrm{7.2,} 0.001 \mathrm{M} \mathrm{EDTA})$ at $65^{\circ} \mathrm{C}$. Washes were performed as follows, $0.5 \%$ SSC/0.1\% SDS for $10 \mathrm{~min}$ at room temperature, $0.5 \% \mathrm{SSC} / 0.1 \% \mathrm{SDS}$ for $10 \mathrm{~min}$ at $65^{\circ} \mathrm{C}$, and 
twice in $0.2 \% \mathrm{SSC} / 0.1 \%$ SDS for $10 \mathrm{~min}$ each at $65^{\circ} \mathrm{C}$. Membranes were developed in phosphoimager cassettes (Molecular Dynamics, Sunnyvale, CA, USA) and visualized using a Storm 840 phosphoimager (Molecular Dynamics, Sunnyvale, CA, USA)

For routine genotyping, tissue was incubated overnight at $55^{\circ} \mathrm{C}$ in $50 \mu \mathrm{l}$ of digestion buffer. The samples were diluted to $400 \mu \mathrm{l}$ with water and $1 \mu \mathrm{l}$ was amplified using a forward primer (5'-CCGAGAGGGACGTGTCGA-3') and a reverse primer (5'-GCCTCCCTGAACGCCTCG-3') both located in the IGF-II transgene (primers 2 and 3; Figure 1A). Forward (5'-CTAGGCCACAGAATTGAAAGATCT-3') and reverse (5'-GTAGGTGGAAATTCTAGCATCATCC- $3^{\prime}$ ) primers for the mouse interleukin-2 gene were also included in each reaction and served as a positive control. The IGF-II and interleukin-2 primers produced $187 \mathrm{bp}$ and $324 \mathrm{bp}$ bands, respectively.

\section{RT - PCR and quantitative RT - PCR}

RNA was extracted from mammary tissue using the method of Chomczynski and Sacchi. ${ }^{83}$ RNA was reverse transcribed using Superscript II reverse transcriptase (Gibco BRL, Burlington, ON, Canada). The resulting cDNAs were amplified using a forward primer (5'-GCCATCCCGTCTCCGCTCGTCACTTATC-3') located in the transcribed segment of the MMTV promoter and a reverse primer (5'GCCTCCCTGAACGCCTCG-3') located in the IGF-II transgene (primers 1 and 3; Figure 1A). Forward and reverse primers for interleukin-2 (described above) were used to ensure that each PCR reaction worked. PCR products were separated on a $1.8 \%$ agarose ge and transferred to nylon membrane. Transgene-specific expression was confirmed using a ${ }^{32} \mathrm{P}$-dCTP-labeled Ha-ras probe (transgene-specific probe, Figure 1A) and hybridization conditions described above.

The level of transgene expression was determined in mammary glands from 35-day-old female transgenics and their littermate controls using quantitative RT-PCR. RNA was reverse transcribed and amplified using a forward and reverse primer specific for IGF-II transgene (described above) and a forward (5'-GTTGGATACAGGCCAGACTTTGTTG-3') and reverse primer (5'-GATTCAACTTGCGCTCATCTTAGGC- $3^{\prime}$ ) for the house keeping gene hypoxanthine phosphoribosyl transferase (HPRT). It was determined that 23 cycles of PCR fell within the linear range of amplification for both the IGF-II primers and the HPRT primers. Following 23 cycles of PCR, samples were electrophoresed through a $1.8 \%$ agarose gel, transferred to nylon membrane and probed with either a ${ }^{32} \mathrm{P}$-dCTP-labeled human IGF-II or a ${ }^{32} \mathrm{P}$-dCTP-labeled HPRT probe. Membranes were developed and the radioactive signal from IGF-II was quantified relative to that of HPRT using a phosphoimager as described above.

\section{Slot blot analysis}

Two micrograms of mammary RNA was heated to $68^{\circ} \mathrm{C}$ for $15 \mathrm{~min}$ in a solution containing $50 \%$ formamide, $7 \%$ formaldehyde and $1 \times$ SSC. Two volumes of $20 \times$ SSC was added to each sample and the samples were loaded on to nylon membranes (pre-soaked in $20 \times$ SSC for $1 \mathrm{~h}$ ) using a Minifold II slot-blot system (Schleicher \& Schuell, Keene, $\mathrm{NH}$, USA) followed by gentle suction. Each well was rinsed once with $10 \times$ SSC followed again by gentle suction. Hybridization of the membrane with the appropriate ${ }^{32} \mathrm{P}$-labeled probe and subsequent washes were performed as described above.

\section{In Situ hybridization}

Antisense probes for human IGF-II or Ha-ras were generated by incorporating digoxygenin (DIG)-labeled UTP (Boehringer Mannheim,
Laval, PQ, Canada) following the manufacturer's protocol. DIG in situ hybridization was performed essentially as previously described ${ }^{84,85}$ with the following modifications. Specifically, tissue was fixed in $4 \%$ $(\mathrm{w} / \mathrm{v})$ buffered formalin overnight, tissue sections were treated with $20 \mu \mathrm{g} / \mathrm{ml}$ of Proteinase $\mathrm{K}$ for $20 \mathrm{~min}$ at room temperature and sections were washed three times in $4 \times$ SSC for $15 \mathrm{~min}$ each at room temperature.

\section{Western analysis and ligand blotting}

Mammary tissue was homogenized in lysis buffer (10 mM Tris pH 7.6, $5 \mathrm{mM}$ EDTA, $50 \mathrm{mM} \mathrm{NaCl}, 1 \%$ Triton-X, $30 \mathrm{mM}$ tetra-sodium pyrophosphate, $500 \mu \mathrm{M}$ sodium orthovanadate, $50 \mathrm{mM}$ sodium fluoride, $1 \mathrm{mM}$ PMSF, $5 \mu \mathrm{g} / \mathrm{ml}$ aprotinin, $1 \mu \mathrm{g} / \mathrm{ml}$ pepstatin, $2 \mu \mathrm{g} / \mathrm{ml}$ leupeptin) and lysates were collected following centrifugation at $15000 \times g$ for $20 \mathrm{~min}$ at $4^{\circ} \mathrm{C}$. Protein concentrations were determined using Bradford assay reagents (Bio-Rad, Hercules, CA, USA). Reduced proteins were separated through $8 \%$ polyacrylamide gels for Akt, PTEN, and Erk1/Erk2 and 6\% gels for IRS-1 using an Xcell II min cell system (Novex, San Diego, CA, USA). Proteins were transferred to Hybond ECL nitrocellulose membranes (Amersham Pharmacia Biotech, Buckinghamshire, UK) at $25 \mathrm{~V}$ for $90 \mathrm{~min}$ and the membranes were blocked in $5 \%$ skim milk in tris-buffered saline containing $1 \%$ tween (TBST) for $2 \mathrm{~h}$ at room temperature. Primary antibody for Akt, phosphorylated Akt(Ser473), Erk1/Erk2 and phosphorylated Erk1/Erk2(Thr202/Tyr204) (New England Biolabs, Beverly, MA, USA) were incubated at a dilution of $1: 1000$ in $5 \%$ skim milk in TBST with the membranes overnight at $4{ }^{\circ} \mathrm{C}$. The primary phospho-IRS-1 antibody (Ser612) (Medicorp, Montreal, QU, Canada) was used at a concentration of $0.5 \mu \mathrm{g} / \mathrm{ml}$ and the primary IRS-1 antibody (Upstate Biotechnology, Lake Placid, NY, USA) was used at a 1:1000 dilution. The antibody for PTEN (New England Biolabs, Beverly, MA, USA) was used at a dilution of $1: 1000$ in $5 \%$ BSA in TBST. Proteins were detected using an HRP-conjugated anti-rabbit secondary antibody and LumiGLO reagents (New England Biolabs, Beverly, MA, USA) and were quantified using a densitometer (Molecular Dynamics, Sunnyvale, CA, USA). Sequential probing of membranes was performed after stripping in $62.5 \mathrm{mM}$ Tris $\mathrm{pH} 6.7$, $100 \mathrm{mM}$ 2-mercaptoethanol, $2 \% \mathrm{SDS}$ for $30 \mathrm{~min}$ at $50^{\circ} \mathrm{C}$. Ligand blotting of wild-type and transgenic involuting mammary tissue was performed as we have previously described. ${ }^{14}$

\section{Whole mount analysis}

The 4th-inguinal mammary glands were removed from mice and placed on glass slides. After air-drying for $10 \mathrm{~min}$, the mammary tissue was fixed overnight in Clarke's solution (75\% ethanol, $25 \%$ glacial acetic acid). Fixed mammary glands were dehydrated in $70 \%$ ethanol for $30 \mathrm{~min}$ and stained overnight in carmine alum $(0.2 \%$ carmine $(\mathrm{w} / \mathrm{v})$ and $0.5 \%$ aluminum potassium sulfate $(\mathrm{w} / \mathrm{v}))$. The mammary glands were then destained $(35 \% \mathrm{HCl}, 70 \%$ ethanol) for $3-4 \mathrm{~h}$, dehydrated in increasing concentrations of ethanol and defatted in toluene. Images were captured using a Sony $3 C C D$ color video camera attached to a Leica MZ12 microscope (Leica Microsystems Inc., Buffalo, NY, USA) and Northern Eclipse Software (Empix Imaging Inc. Mississauga, ON, Canada).

\section{Immunohistochemistry and histological staining}

Mammary glands were fixed in $4 \%(\mathrm{w} / \mathrm{v})$ buffered formalin overnight at room temperature prior to embedding. Paraffin sections were dewaxed in toluene and re-hydrated in decreasing concentrations of alcohol. To detect apoptotic cells in wild-type and transgenic involuting 
mammary tissue, sections were digested with Proteinase $\mathrm{K}(20 \mu \mathrm{g} / \mathrm{ml})$ at room temperature for $15 \mathrm{~min}$ and terminal end-labeling of fragmented DNA in apoptotic cells was performed using an Apop Tag in situ apoptosis detection kit (Intergen, Purchase, NY, USA) following the manufacturer's protocol. Detection of apoptotic cells in the pellet experiments and bromodeoxyuridine (BrdU) immunohistochemistry were performed as previously described. ${ }^{86,87}$

\section{Elvax-40 slow release pellets}

Elvax-40 pellets containing recombinant human IGF-II (rIGF-II) (Calbiochem, San Diego, CA, USA) were generated as previously described. ${ }^{87}$ Pellets containing $500 \mathrm{ng}$ of rIGF-II were implanted in the 4th-inguinal mammary gland of wild-type mice at day 2 of involution. Control pellets containing only the vehicle (PBS) were implanted in the contralateral mammary gland. The mice were sacrificed 3 days later and the 4th-inguinal mammary glands along with the control or IGF-II pellets were isolated for analysis.

\section{Statistics}

All values are presented as mean \pm SEM. Statistical significance was determined using the Student's $t$-test and values were considered significant when $P<0.05$.

\section{Acknowledgements}

We thank Dr. Otto H Sanchez-Sweatman for expertise in histopathology and Dr. Paul Waterhouse for critical reading of the manuscript. This work was supported with funds from the National Cancer Institute and the Medical Research Council of Canada to R Khokha. RA Moorehead was supported by Postdoctoral Fellowships from Amgen and the George Knudson Foundation and is currently supported by a Postdoctoral Fellowship from the US Army Medical Research and Materiel Command. JE Fata is currently supported by a University of Toronto Open Scholarship and a Princess Margaret Hospital Graduate Scholarship.

\section{References}

1. Papa V, Gliozzo B, Clark GM, McGuire WL, Moore D, Fujita-Yamaguchi Y, Vigneri R, Goldfine ID and Pezzino V (1993) Insulin-like growth factor I receptors are overexpressed and predict a low risk in human breast cancer. Cancer Res. 53: $3735-3740$

2. Helle SI and Lonning PE (1996) Insulin-like growth factors in breast cancer. Acta. Oncol. 35(suppl) 5: 19-22

3. Ellis MJC, Singer C, Homby A, Rasmussen A and Cullen KJ (1994) Insulin-like growth factor mediated stromal-epithelial interactions in human breast cancer. Breast Cancer Res. Treat. 31: 249-261

4. WernerHandLe Roith D (1996) The role of the insulin-like growth factor system in human cancer. Adv. Cancer Res. 68: 183-223

5. Adamo M, Lowe Jr. WL, Le Roith D and Roberts Jr. CT (1989) Insulin-like growth factor I messenger ribonucleic acids with alternative $5^{\prime}$-untranslated regions are differentially expressed during development of the rat. Endocrinology 124: 2737-2744

6. Adamo ML, Bach MA, Roberts Jr. CT and Le Roith D (1991) Le Roith D (ed). Insulin-like growth factors. CRC Press, Boca Raton, FL: 271-303

7. Roberts Jr. CT, Brown AL, Graham DE, Seelig S, Berry S, Gabbay KH and Rechler MM (1986) Growth hormone regulates the abundance of insulin-like growth factor I RNA in adult rat liver. J. Biol. Chem. 261: 10025-10028

8. DeChiara TM, Robertson EJ and Efstratiadis A (1991) Parental imprinting of the mouse insulin-like growth factor II gene. Cell 64: 849-859
9. Liu J-P, Baker J, Perkins AS, Robertson EJ and Efstratiadis A (1993) Mice carrying null mutations of the genes encoding insulin-like growth factor I (Igf-1) and type I IGF receptor (Igf1r). Cell 75: 59-72

10. Baker J, Liu J-P, Robertson EJ and Efstratiadis A (1993) Role of insulin-like growth factors in embryonic and postnatal growth. Cell 75: 73-82

11. Werner $H$ and Le Roith D (1997) The insulin-like growth factor-I receptor signaling pathways are important for tumorigenesis and inhibition of apoptosis. Crit. Rev. Oncog. 8: 71-92

12. Paik S (1992) Expression of IGF-I and IGF-II mRNA in breast tissue. Breast Cancer Res. Treat. 22: 31-38

13. Yee D, Paik S, Lebovic GS, Marcus RR, Favoni RE, Cullen KJ, Lippman ME and Rosen N (1989) Analysis of insulin-like growth factor I gene expression in malignancy: evidence for a paracrine role in human breast cancer. Mol. Endocrinol. 3: 509-517

14. Martin DC, Fowlkes JL, Babic B and Khokha R (1998) Insulin-like growth factor-II signaling is blocked by transgenic expression of the metalloproteinase inhibitor TIMP-1. J. Cell Biol. 146: 881-892

15. Christofori G, Naik P and Hanahan D (1994) A second signal supplied by insulinlike growth factor II in oncogene-induced tumorigenesis. Nature 369: 414-418

16. Bates P, Fisher R, Ward A, Richardson L, Hill DJ and Graham CF (1995) Mammary cancer in transgenic mice expressing insulin-like growth factor II (IGFII). Br. J. Cancer 72: 1189-1193

17. Neuenschwander S, Schwartz A, Wood TL, Roberts Jr. CT and Henninghausen $L$ (1996) Involution of the lactating mammary gland is inhibited by the IGF system in a transgenic mouse model. J. Clin. Invest. 97: 2225-2232

18. Zhang W, Ghetti B and Lee WB (1997) Decreased IGF-I gene expression during the apoptosis of Purkinje cells in pcd mice. Brain Res. Dev. Brain Res. 98: 164 176

19. Ellouk-Achard S, Djenabi S, De Oliveira GA, Desauty G, Duc HT, Zohair M, Trojan J, Claude JR, Sarasin A and Lafarge-Frayssinet C (1998) Induction of apoptosis in rat hepatocarcinoma cells by expression of IGF-I antisense c-DNA. J. Hepatol. 29: $807-818$

20. Hirschberg R and Ding H (1998) Mechanisms of insulin-like growth factor-Iinduced accelerated recovery in experimental ischemic acute renal failure. Miner Electrolyte Metab. 24: 211-219

21. Werther GA, Russo V, Baker N and Butler G (1998) The role of insulin-like growth factor system in the developing brain. Horm. Res. 49(suppl.1): $37-40$

22. Leri A, Liu Y, Wang X, Kajstura J, Malhotra A, Meggs LG and Anversa P (1999) Overexpression of insulin-like growth factor-1 attenuates the myocyte reninangiotensin system in transgenic mice. Circ. Res. 84: 752-762

23. Nickerson T and Huynh H (1999) Vitamin D analogue EB1089-induced prostate regression is associated with increased gene expression of insulin-like growth factor binding proteins. J. Endocrinol. 160: 223-229

24. Werb Z, Ashkenas J, MacAuley A and Wiesen JF (1996) Extracellular matrix remodeling as a regulator of stromal-epithelial interactions during mammary gland development, involution and carcinogenesis. Braz. J. Med. Biol. Res. 29: 1087-1097

25. Strange R, Friss RR, Bemis LT and Geske FJ (1995) Programmed cell death during mammary gland involution. Meth. Cell Biol. 46: 355-368

26. Talhouk RS, Bissell MJ and Werb Z (1992) Coordinated expression of extracellular matrix-degrading proteinases and their inhibitors regulates mammary epithelial function during involution. J. Cell Biol. 118: 12711282

27. Lund LR, Romer J, Thomasset N, Solberg H, Pyke C, Bissell MJ, Dano K and Werb Z (1996) Two distinct phases of apoptosis in mammary gland involution: proteinase-independent and -dependent pathways. Development 122: $181-$ 193

28. Jaggi R, Marti A, Guo K, Feng Z and Friis RR (1995) Regulation of a physiological apoptosis: mouse mammary involution. J. Dairy Sci. 79: 1074-1084

29. Li M, Liu X, Robinson G, Bar-Peled U, Wagner K-U, Young WS, Hennighausen L and Furth PA (1997) Mammary-derived signals activate programmed cell death during the first stage of mammary gland involution. Proc. Natl. Acad. Sci. USA 94: $3425-3430$

30. Quarrie LH, Addey CVP and Wilde CJ (1996) Programmed cell death during mammary tissue involution induced by weaning, litter removal, and milk stasis. Journal of Cellular Physiology 168: 559-569

31. Feng Z, Marti A, Jehn B, Altermatt HJ, Chicaiza G and Jaggi R (1995) Glucocorticoid and progesterone inhibit involution and programmed cell death in the mouse mammary gland. J. Cell. Biol. 131: 1095-1103 
32. Muller WJ, Sinn E, Pattengale PK, Wallace R and Leder P (1988) Single-step induction of mammary adenocarcinoma in transgenic mice bearing the activated c-neu oncogene. Cell 54: 105-115

33. Guy CT, Webster MA, Schaller M, Parson TJ, Cardiff RD and Muller WJ (1992) Expression of the neu proto-oncogene in the mammary epithelium of transgenic mice induces metastatic disease. Proc. Natl. Acad. Sci. USA 89: 10578-10582

34. Richert MM and Wood TL (1999) The insulin-like growth factors (IGF) and IGF type 1 receptor during postnatal growth of murine mammary gland: sites of messenger ribonucleic acid expression and potential functions. Endocrinology 140: 454-461

35. Clemmons DR (1998) Role of insulin-like growth factor binding proteins in controlling IGF actions. Mol. Cell Endocrinol. 140: 19-24

36. Oh Y (1998) IGF-independent regulation of breast cancer growth by IGF binding proteins. Breast Cancer Res. Treat. 47: 283-293

37. Tonner E, Barber MC, Travers MT, Logan A and Flint DJ (1997) Hormonal control of insulin-like growth factor-binding protein-5 production in the involuting mammary gland of the rat. Endocrinology 138: 5101-5107

38. White MF and Kahn CR (1994) The insulin signaling system. J. Biol. Chem. 269 $1-4$

39. Frasca F, Pandini G, Scalia P, Sciacca L, Mineo R, Costantino A, Goldfine ID, Belfiore $A$ and Vigneri $R$ (1999) Insulin receptor isoform A, a newly recognized, high affinity insulin-like growth factor II receptor in fetal and cancercells. Mol. Cell Biol. 19: 3278-3288

40. Belfiore A, Pandini G, Vella S, Squatrito S and Vigneri R (1999) Insulin/IGF-I hybrid receptors play a major role in IGF-I signaling in thyroid cancer. Biochimie. 81: $403-407$

41. Heermeier K, Benedict M, Li M, Furth P and Henninghausen L (1996) Bax and $\mathrm{Bcl}-\mathrm{x}_{\mathrm{S}}$ are induced at the onset of apoptosis in involuting mammary epithelia cells. Mech. Devel. 56: 197-207

42. Kulik G, Kippel A and Weber MJ (1997) Antiapoptotic signalling by the insulin-like growth factorl receptor, phosphatidylinositol3-kinase, and Akt. Mol. Cell Biol. 17: $1595-1606$

43. Kulik G and Weber MJ (1998) Akt-dependent and -independent survival signaling pathways utilized by insulin-like growth factor I. Mol. Cell Biol. 18 : $6711-6718$

44. O'Connor R, Kauffmann-Zeh A, Liu Y, Lehar S, Evan Gl, Baserga R and Blattler WA (1997) Identification of domains of the insulin-like growth factor I receptor that are required for protection from apoptosis. Mol. Cell Biol. 17: 427-435

45. Ahmad S, Singh N and Glazer RI (1999) Role of AKT1 in 17beta-estradiol- and insulin-like growth factor I (IGF-I)-dependent proliferation and prevention of apoptosis in MCF-7 breast carcinoma cells. Biochem. Pharmacol. 58: 425-430

46. Di Christofano A and Pandolfi PP (2000) The multiple roles of PTEN in tumor suppression. Cell 100: 387-390

47. Stambolic V, Suzuki A, de la Pompa JL, Brothers GM, Mirtsos C, Sasaki T, Ruland J, Penninger JM, Siderovski DP and Mak TW (1998) Negative regulation of PKB/Akt-dependent cell survival by the tumor suppressor PTEN. Cell 95:2939

48. Nakashima N, Sharma PM, Imamura T, Bookstein R and Olefsky JM (2000) The tumor suppressor PTEN negatively regulates insulin signaling in 3T3-L1 adipocytes. J. Biol. Chem. 275: 12889-12895

49. Datta SR, Brunet A and Greenberg ME (1999) Cellular survival: a play in three Akts. Genes Devel. 13: 2905-2927

50. Cross TG, Scheel-Toeliner D, Henriquez NV, Deacon E, Salmon M and Lord JM (2000) Serine/threonine protein kinases and apoptosis. Exp. Cell Res. 256: $34-$ 41

51. Kandel ES and Hay $N$ (1999) The regulation and activities of the multifunctional serine/threonine kinase Akt/PKB. Exp. Cell Res. 253: 210-229

52. Scheid MP, Schubert KM and Duronio V (1999) Regulation of Bad phosphorylation and association with $\mathrm{Bcl}-\mathrm{x}_{\mathrm{L}}$ by the MAPK/Erk kinase. J. Biol. Chem. 274: 31108-31113

53. Scheid MP and Duronio V (1998) Dissociation of cytokine-induced phosphorylation of Bad and activation of PKB/akt: Involvement of MEK upstream of Bad phosphorylation. Proc. Natl. Acad. Sci. USA 95: 7439-7444

54. Prosser CG, Fleet IR, Corps AN, Froesch ER and Heap RB (1995) Increase in milk secretion and mammary blood flow by intra-arterial infusion of insulin-like growth factor-l into the mammary gland of the goat. J. Endocrinol. 126: 437-443

55. Tonner E, Quarrie L, Travers M, Barber M, Logan A, Wilde C and Flint D (1996) Does an IGF-binding protein (IGFBP) present in involuting rat mammary gland regulate apoptosis. Prog. Growth Factor Res. 6: 409-414
56. Flint DJ, Tonner E, Beattie J and Gardner M (1994) Several insulin-like growth factor-I analogues and complexes of insulin-like growth factors-I and -II with insulin-like growth factor-binding protein-3 fail to mimic the effect of growth hormone upon lactation in the rat. J. Endocrinol. 140: 211-216

57. Chapman RS, Lourenco PC, Tonner E, Flint DJ, Selbert S, Takeda K, Akira S, Clarke AR and Watson CJ (1999) Suppression of epithelial apoptosis and delayed mammary gland involution in mice with a conditional knockout of Stat3. Genes. Devel. 13: 2604-2616

58. LeRoith D, Neuenschwander S, Wood TL and Henninghausen L (1995) Insulinlike growth factor-I and insulin-like growth factor binding protein-3 inhibit involution of the mammary gland following lactation: studies in transgenic mice. Prog. Growth Factor Res. 6: 433-436

59. Murphy LG, Bell Gl and Friesen HG (1987) Tissue distribution of insulin-like growth factor I and II messenger ribonucleic acid in the adult rat. Endocrinology 120: $1279-1282$

60. Rogler CE, Yang D, Rossetti L, Donohoe J, Alt E, Chang CJ, Rosenfeld R, Neely $\mathrm{K}$ and Hintz R (1994) Altered body composition and increased frequency of diverse malignancies in insulin-like growth factor-II transgenic mice. J. Biol. Chem. 269: 13779-13784

61. Wolf $\mathrm{E}$, Hoeflich $A$ and Lahm $\mathrm{H}$ (1998) What is the function of IGF-II in postnatal life? Answers from transgenic mouse models. Growth Horm IGF Res. 8: 185193

62. Martin DC, Sanchez-Sweatman OH, Ho AT, Inderdeo DS and Khokha R (1997) Transgenic TIMP-1 inhibits proliferation and angiogenesis in an SV40 T-antigen tumor model. Lab. Invest. 79: 225-234

63. Ferguson DJP and Anderson TJ (1981) Morphological evaluation of cell turnover in relation to the menstrual cycle in the 'resting' human breast. Br. J. Cancer. 44: $177-181$

64. Jager R, Herzer U, Schenkel J and Weiher H (1997) Overexpression of Bcl-2 inhibits alveolar cell apoptosis during involution and accelerates c-myc-induced tumorigenesis of the mammary gland in transgenic mice. Oncogene 15: 17871795

65. Allan DJ, Howell A, Roberts SA, Williams GT, Watson RJ, Coyne JD, Clarke RB, Laidlaw IJ and Potten CS (1999) Reduction in apoptosis relative to mitosis in histologically normal epithelium accompanies fibrocystic change and carcinoma of the premenopausal human breast. J. Pathol. 167: 25-32

66. Cardone MH, Roy N, Stennicke HR, Salvesen GS, Franke TF, Stanbridge E, Frisch S and Reed JC (1998) Regulation of cell death protease caspase 9 by phosphorylation. Science 282: 318-321

67. Merlo GR, Cella N and Hynes NE (1997) Apoptosis is accompanied by changes in $\mathrm{Bcl}-2$ and Bax expression, induced by loss of attachment, and inhibited by specific extracellular matrix proteins in mammary epithelial cells. Cell. Growth. Diff. 8: 251-260

68. Pullan S, Wilson J, Metcalfe A, Edwards GM, Goberdhan N, Tilly J, Hickman JA, Dive $C$ and Streuli $\mathrm{CH}$ (1996) Requirement of basement membrane for the suppression of programmed cell death in mammary epithelium. J. Cell. Sci. 109: $631-642$

69. Farrelly N, Lee Y-J, Oliver J, Dive C and Streuli CH (1999) Extracellular matrix regulates apoptosis in mammary epithelium through a control of insulin signaling. J. Cell. Biol. 144: 1337-1347

70. Blackburn A, Dressendorfer RA, Blum WF, Erhard M, Brem G, Strasburger CJ and Wolf $E$ (1997) Interactions of insulin-like growth factor (IGF)-II and growth hormone in vivo: circulating levels of IGF-I and IGF-binding proteins in transgenic mice. Eur. J. Endocrinol. 137: 701-708

71. Wolf E, Kramer R, Blum WF, Foll J and Brem G (1994) Consequences of postnatally elevated insulin-like growth factor-II in transgenic mice: endocrine changes and effects on body and organ growth. Endocrinology 135: 1877-1886

72. Van der Ven LTM, Roholl PJM, Reijnen MG, Bloemen RJ and van Buul-Offers SC (1997) Expression of insulin-like growth factor II (IGF-II) and histological changes in the thymus and spleen of transgenic mice overexpressing IGF-II. Histochem. Cell. Biol. 107: 193-203

73. Smink JJ, Koster JG, Hendriks-Stegeman BI and van Buul-Offers SC (1999) Insulin-like growth factor (IGF) II induced changes in expression of IGF binding proteins in lymphoid tissues of hIGF-II transgenic mice. Endocrinology 140: $5876-5882$

74. Kooijman R, van Buul-Offers SC, Scholtens LE, Schuurman H-J, Van den Brande LJand Zegers BJ (1995) T cell development in insulin-like growth factor-II transgenic mice. J. Immunol. 154: 5736-5745 
75. Kooijman R, van Buul-Offers SC, Scholtens LE, Reijnen-Gresnigt RG and Zegers BJ (1997) T and B cell development in pituitary deficient insulin-like growth factor-II transgenic dwarf mice. J. Endocrinol. 155: 165-170

76. van Buul-Offers SC, de Haan K, Reijnen-Gresnigt MG, Meinsma D, Jansen M, Oei SL, Bonte EJ, Sussenbach JS and Van den Brande LJ (2000) Overexpression of human insulin-like growth factor-II in transgenic mice caused increased growth of the thymus. J. Endocrinol. 144: 491-502

77. Rooman R, Koster JG, Bloemen R, Gresnigt R and van Buul-Offers SC (1999) The effect of dexamethasone on body and organ growth of normal and IGF-IItransgenic mice. J. Endocrinol. 163: 543-552

78. Weber MM, Fottner C, Schmidt P, Brodowski KMH, Gittner K, Lahm H Engelhardt $D$ and Wolf $E$ (1999) Postnatal overexpression of insulin-like growth factor II in transgenic mice is associated with adrenocortical hyperplasia and enhanced steroidogenesis. Endocrinology 140: 1537-1543

79. Huynh H, Seyam RM and Brock GB (1998) Reduction of ventral prostate weight by finasteride is associated with suppression of insulin-like growth factor I (IGF-I) and IGF-I receptor genes and with an increase in IGF binding protein 3. Cancer Res. 58: 215-218

80. Selbert S, Bentley DJ, Melton DW, Rannie E, Lourenco P, Watson CJ and Clarke AR (1998) Efficient BLG-Cre mediated gene deletion in the mammary gland. Transgenic Res. 7: 387-396

81. Clarke AJ (1998) Gene expression in the mammary glands of transgenic animals. Biochem. Soc. Symp. 63: 133-140
82. Baruch A, Shani M, Hurwitz DR and Barash I (1995) Developmental regulation of the ovine beta-lactoglobulin/human serum albumin transgene is distinct from that of the beta-lactoglobulin and the endogenous beta-casein genes in the mammary gland of transgenic mice. Dev. Genet. 16: 241-252

83. Chomczynski Pand Sacchi N (1987) Single-step method of RNA isolation by acid guanidium thiocyanate-phenol-chloroform extraction. Anal. Biochem. 162: $156-159$

84. Inderdeo DS, Edwards DR, Han VKM and Khokha R(1996) Temporal and spatial expression of tissue inhibitors of metallop roteinases during the natural ovulatory cycle of the mouse. Biol. Reprod. 55: 498-508

85. Harvey MB, Leco KJ, Arcellana-Panlilio MY, Zhang X, Edwards DR and Schultz GA (1995) Proteinase expression in early mouse embryos is regulated by leukemia inhibitory factor and epidermal growth factor. Development 121 $1005-1014$

86. Wijsman JH, Jonker RR, Keijzer R, Van De Velde CJH, Cornelisse CJ and Van Dierendonck JH (1993) A new method to detect apoptosis in paraffin sections: In situ end-labeling of fragmented DNA. J. Histochem. Cytochem. 1: 7-12

87. Fata JE, Leco KJ, Moorehead RA, Martin DC and Khokha R (1998) Ductal epithelial proliferation is affected by TIMP expression during mammary morphogenesis. Devel. Biol. 211: 238-254 